\title{
PENGEMBANGAN KOMPETENSI GURU PENDIDIKAN DASAR PASCA SERTIFIKASI
}

\author{
Dewi Nofrita \\ Dosen Tetap Jurusan Tarbiyah STAIN AL-Fatah Jayapura
}

\begin{abstract}
In order to achieve basic education goals, so the development of teachers and other educator are developed to improve the quality of education throughout the country. Education is improved and integrated cohesively in adequate amounts quality. Furthermore, the basic education of teachers is required to work regularly and consistently, but being creative in facing the job and stability in the works, should be personal characteristics. So, this pattern of this work's type is inspired by learners by learners as education, since the stability and personal integration does not happen by itself, but growing through a process of education which is deliberately created.
\end{abstract}

Keywords: Teacher competence, basic education

\section{A. Pendahuluan}

Pendidikan dasar merupakan pendidikan sembilan tahun, yang bertujuan untuk memberikan bekal kemampuan dasar kepada peserta didik untuk mengembangkan kehidupannya sebagai pribadi, anggota masyarakat, warga negara dan anggota umat manusia serta mempersiapkan peserta didik untukmengikuti pendidikan menengah. Dalam rangka mencapai tujuan pendidikan dasar di atas, maka pembinaan guru serta tenaga kependidikan lainnya dikembangkan untuk meningkatkan kualitas pendidikan di seluruh tanah air. Kualitas pendidikan ditingkatkan dan diselenggarakan secara terpadu dalam jumlah yang memadai.

Pengembangan karier dan kesejahteraan guru serta tenaga kependidikan lainnya ditingkatkan. Demikian juga kualitas dan kemampuan guru diupayakan agar lebih baik lagi dari kualitas dan kemampuan guru sebelumnya, sebab guru pendidikan dasar merupakan faktor 
yang sangat dominan dan paling penting dalam pendidikan karena bagi peserta didik guru pendidikan dasar sering dijadikan tokoh teladan bahkan menjadi tokoh identifikasi diri, oleh sebab itu guru pendidikan dasar seyogyanya memiliki prilaku dan kemampuan secara memadai untuk mengembangkan peserta didik secara utuh dengan melaksanakan tugas secara baik sesuai dengan profesi yang dimiliki guru pendidikan dasar dengan menguasai berbagai hal baik secara teoritis maupun praktis dalam proses kependidikan.

Di sisi lain guru-guru pendidikan dasar harus memahami dan menghayati peserta didik yang dibinanya, karena wujud peserta didik pada setiap saat tidak akan sama sebab perkembangan ilmu pengetahuan dan teknologi memberikan dampak serta nilai-nilai pada budaya masyarakat Indonesia dan sangat mempengaruhi gambaran peserta didik dalam proses kependidikan. Oleh sebab itu gambaran prilaku guru pendidikan dasar yang diharapkan sangat mempengaruhi dan dipengaruhi oleh keadaan itu, sehingga guru pendidikan dasar dalam melaksanakan proses kependidikan mengantisipasi perkembangan keadaan sesuai dengan tuntutan masyarakat di masa mendatang.

Demikian juga guru-guru pendidikan dasar dalam proses kependidikan harus memiliki kemampuan tersendiri guna mencapai harapan yang dicita-citakan dalam melaksanakan pendidikan pada umumnya dan proses belajar-mengajar pada khususnya. Untuk melaksanakan proses kependidikan yang baik guru-guru pendidikan dasar perlu membina diri secara baik, karena fungsi guru itu sendiri adalah membina dan mengembangkan kemampuan peserta didik secara profesional di dalam proses kependidikan.

Dalam membina kemampuan peserta didik pada tingkat pendidikan dasar tentu guru itu sendiri harus memiliki kemampuan tersendiri. Adapun kemampuan yang harus dimiliki guru pendidikan dasar meliputi kemampuan; mengawasi, membina dan mengembangkan kemampuan peserta didik baik secara personal, profesional dan sosial.

Guru pendidikan dasar dituntut untuk dapat bekerja dengan teratur dan konsisten, akan tetapi kreatif dalam menghadapi pekerjaannya dan kemantapan dalam bekerja, hendaknya merupakan karakteristik pribadinya. Sehingga pola kerja seperti ini terhayati 
pula oleh peserta didik sebagai pendidikan, sebab kemantapan dan integrasi pribadi tidak terjadi dengan sendirinya, melainkan tumbuh melalui proses kependidikan yang sengaja diciptakan.

\section{B. Peranan Guru Pendidikan Dasar}

Peranan guru pendidikan dasar dalam proses kependidikan meliputi banyak hal sebagaimana yang dikemukakan oleh Adam \& Decey (dalam Rusyan, 1993:6), antara lain guru sebagai pengajar, pemimpin kelas, pembimbing, pengatur lingkungan, partisipan, ekspeditor, perencana, supervisor, motivator, penanya, evaluator dan konselor, yang akan dikemukakan di sini adalah peranan yang dianggap paling dominan dan diklasifikasikan sebagai berikut.

1) Guru Pendidikan Dasar sebagai Demonstrator

Peranan guru pendidikan dasar sebagai demonstrator, hendaknya senantiasa menguasai bahan atau materi pelajaran yang akan diajarkannya serta senantiasa mengembangkannya dalam arti meningkatkan kemampuannya dalam hal ilmu yang dimilikinya karena hal ini akan sangat menentukan hasil belajar yang dicapai oleh peserta didik.

\section{2) Guru Pendidikan Dasar sebagai Pengelola Kelas}

Peranan guru pendidikan dasar sebagai pengelolaan kelas hendaknya mampu mengelola kelas, karena merupakan lingkungan belajar serta merupakan suatu aspek dari lingkungan sekolah yang perlu diawasi agar kegiatan-kegiatan belajar terarah kepada tujuan-tujuan pendidikan. Pengawasan terhadap lingkungan itu turut menentukan sejauh mana lingkungan tersebut menjadi lingkungan belajar yang baik. Lingkungan yang baik adalah yang bersifat menantang dan merangsang peserta didik untuk belajar, memberikan rasa aman dan kepuasan dalam mencapai tujuan.

\section{3) Guru Pendidikan Dasar sebagai Mediator dan Fasilitator}

Sebagai mediator guru pendidikan dasar menjadi perantara dalam hubungan antar manusia. Untuk keperluan itu guru pendidikan dasar harus terampil mempergunakan pengetahuan tentang bagaimana orang berinteraksi dan berkomunikasi. Tujuannya ialah agar guru pendidikan dasar dapat menciptakan secara maksimal kualitas lingkungan yang interaktif. Dalam hal ini ada tiga macam kegiatan 
yang dapat dilakukan oleh guru pendidikan dasar, yaitu mendorong berlangsungnya tingkah laku sosial yang baik, mengembangkan gaya interaksi pribadi, dan menumbuhkan hubungan-hubungan yang positif dengan peserta didik.

Sebagai fasilitator guru pendidikan dasar hendaknya mampu mengusahakan sumber belajar yang kiranya berguna serta dapat menunjang pencapaian tujuan dan proses kependidikan baik yang berupa narasumber, buku teks, majalah, atau pun surat kabar.

4) Guru Pendidikan Dasar sebagai Evaluator

Dalam fungsinya sebagai penilai hasil belajar peserta didik guru pendidikan dasar hendaknya secara terus menerus mengikuti hasil-hasil belajar yang telah dicapai peserta didik dari waktu ke waktu. Informasi yang diperoleh melalui evaluasi ini akan merupakan umpan balik (feedback) terhadap proses kependidikan. Umpan balik ini akan dijadikan titik-tolak untuk memperbaiki dan meningkatkan proses kependidikan selanjutnya. Dengan demikian, proses kependidikan akan terus-menerus ditingkatkan untuk memperoleh hasil yang optimal.

\section{Kemampuan Guru Pendidikan Dasar}

1) Pengertian Kemampuan Guru Pendidikan Dasar

Istilah kemampuan mempunyai banyak makna, Broke and Stone; menjelaskan bahwa; Kemampuan merupakan gambaran hakikat kualitatif dari prilaku guru atau tenaga kependidikan yang nampak sangat berarti. Pendapat lain mengenai kemampuan dikemukakan oleh Charles E. Jhonsons Cs. (dalam Rusyan, 1993:12), kemampuan merupakan prilaku yang rasional untuk mencapai tujuan yang dipersyaratkan sesuai dengan kondisi yang diharapkan.

Bertolak dari kedua pendapat di atas, kompetensi mengacu kepada kemampuan melaksanakan sesuatu yang diperoleh melalui pendidikan; kompetensi menunjuk kepada performance dan perbuatan yang rasional, untuk memenuhi verifikasi tertentu di dalam pelaksanaan tugas-tugas kependidikan. Dikatakan rasional karena mempunyai arah atau tujuan, sedangkan, performance merupakan prilaku nyata dalam arti tidak hanya dapat diamati saja, tetapi meliputi yang lebih jauh dari itu yang tidak nampak. Kemampuan guru merupakan salah satu hal yang harus dimiliki dalam jenjang 
pendidikan apa pun, karena kemampuan itu memiliki kepentingan tersendiri, dan sangat penting untuk dimiliki oleh guru, sebab:

(a) Kemampuan guru sebagai alat seleksi dalam penerimaan calon garu. Dengan adanya syarat sebagai kriteria penerimaan calon guru, maka akan terdapat pedoman bagi para administrator dalam memilih guru yang diperlukan untuk satu sekolah. Asumsi yang mendasarinya adalah bahwa setiap guru yang memenuhi syarat tersebut diharapkan akan berhasil dalam mengemban tugasnya sebagai pengajar di sekolah. Untuk itu pemilihan guru tidak didasarkan atas suka sama suka atau karena family yang bersifat subyektif, tetapi atas dasar objektivitas yang berlaku secara umum untuk semua calon guru.

(b) Kemampuan guru penting dalam pembinaan karena jika telah ditentukan dasar ukuran mana guru yang telah memiliki kemampuan penuh dan mana yang masih kurang. Informasi ini sangat penting dalam usaha pembinaan dan pengembangan para guru. Guru yang memiliki kemampuan penuh tentu perlu dibina terus agar kemampuannya tetap mantap, sedangkan guru yang memiliki kemampuan di bawah standar, administrator dapat menyusun perencanaan yang relevan agar guru tersebut dapat memiliki kemampuan yang sama atau seimbang dengan kemampuan guru yang lainnya, misalnya dengan jalan diadakan penataran atau melanjutkan studi ke jenjang pendidikan yang lebih tinggi

(c) Kemampuan guru penting dalam rangka penyusunan kurikulum karena berhasil tidaknya pendidikan guru terletak pada dalam proses pendidikan guru yang salah satu di antaranya adalah komponen kurikulum. Oleh karena itu, kurikulum pendidikan tenaga kependidikan harus disusun berdasarkan kemampuan yang diperlukan oleh setiap guru. Dengan demikian tujuan, program pendidikan, sistim penyampaian, evaluasi dan sebagai harus direncanakan sedemikian rupa agar relevan dengan tuntutan kemampuan guru.

(d) Kemampuan guru penting dalam hubungannya dengan kegiatan belajar-mengajar dan hasil belajar peserta didik karena, proses kependidikan dan hasil belajar yang diperoleh peserta didik bukan saja ditentukan oleh sekolah, pola dan struktur serta isi 
kurikulum nya, tetapi juga ditentukan oleh kemampuan guru yang mengajar itu sendiri dalam membimbing peserta didik. Guru yang mampu akan lebih baik mengelola kelasnya sehingga hasil belajar peserta didik berada pada tingkat optimal.

\section{2) Karakteristik Kemampuan Guru Pendidikan Dasar}

Guru yang profesional yang akan bekerja melaksanakan fungsi dan tujuan sekolah khususnya dan tujuan pendidikan umumnya, sudah barang tentu memiliki kemampuan sesuai dengan tuntutan.

Sebagai indikator, guru pendidikan dasar yang dinilai mampu secara profesional apabila:

(a) Guru tersebut mampu mengembangkan tanggung jawab dengan sebaik-baiknya.

(b) Guru tersebut mampu melaksanakan peranannya secara berhasil.

(c) Guru tersebut mampu bekerja dalam usaha mewujudkan tujuan pendidikan di sekolah.

(d) Guru tersebut mampu melaksanakan peranannya dalam proses belajar-mengajar di kelas. Karakteristik tersebut, agar lebih jelas perlu ditinjau dari berbagai segi, yaitu: kemampuan dasar dalam proses belajar-mengajar.

Seperti telah kita ketahui bahwa dalam proses kependidikan, kemampuan merupakan satu dasar yang paling sering digunakan oleh guru dalam melaksanakan proses belajar-mengajar. Dengan melaksanakan proses belajar-mengajar, diharapkan peserta didik dapat mengetahui, memahami dan mengaplikasikan serta terampil dalam memecahkan masalah-masalah yang terdapat dalam kehidupan sehari-hari. Dengan demikian betapa pentingnya kemauan guru pendidikan dasar memiliki kemampuan secara optimal dalam proses pembelajaran.

3) Macam Kemampuan Guru Pendidikan Dasar

Merujuk pada Undang-undang Guru dan Dosen dimensi kompetensi yang dibutuhkan adalah dimensi (1) pedagogik, (2) profesional, (3) pribadi, dan (4) sosial. Berikut ini akan diuraikan dimensi-dimensi kompetensi tersebut.

\section{(a) Kompetensi Pedagogik}


Dalam Undang-undang No. 14 Tahun 2005 tentang Guru dan Dosen dikemukakan kompetensi pedagogik adalah "kemampuan mengelola pembelajaran peserta didik". Depdiknas (2004:9) menyebut kompetensi ini dengan "kompetensi pengelolaan pembelajaran. Kompetensi ini dapat dilihat dari kemampuan merencanakan program belajar mengajar, kemampuan melaksanakan interaksi atau mengelola proses belajar mengajar, dan kemampuan melakukan penilaian.

(1) Kompetensi Menyusun Rencana Pembelajaran

Menurut Joni (1984:12), kemampuan merencanakan program belajar mengajar mencakup kemampuan: (1) merencanakan pengorganisasian bahan-bahan pengajaran, (2) merencanakan pengelolaan kegiatan belajar mengajar, (3) merencanakan pengelolaan kelas, (4) merencanakan penggunaan media dan sumber pengajaran; dan (5) merencanakan penilaian prestasi siswa untuk kepentingan pengajaran.

Depdiknas (2004:9) mengemukakan kompetensi penyusunan rencana pembelajaran meliputi (1) mampu mendeskripsikan tujuan, (2) mampu memilih materi, (3) mampu mengorganisir materi, (4) mampu menentukan metode/strategi pembelajaran, (5) mampu menentukan sumber belajar/media/ alat peraga pembelajaran, (6) mampu menyusun perangkat penilaian, (7) mampu menentukan teknik penilaian, dan (8) mampu mengalokasikan waktu.

Berdasarkan uraian di atas, merencanakan program belajar mengajar merupakan proyeksi guru mengenai kegiatan yang harus dilakukan siswa selama pembelajaran berlangsung, yang mencakup: merumuskan tujuan, menguraikan deskripsi satuan bahasan, merancang kegiatan belajar mengajar, memilih berbagai media dan sumber belajar, dan merencanakan penilaian penguasaan tujuan.

(2) Kompetensi Melaksanakan Proses Belajar Mengajar

Melaksanakan proses belajar mengajar merupakan tahap pelaksanaan program yang telah disusun. Dalam kegiatan ini kemampuan yang di tuntut adalah keaktifan guru menciptakan dan menumbuhkan kegiatan siswa belajar sesuai dengan rencana yang telah disusun. Guru harus dapat mengambil keputusan atas dasar penilaian yang tepat, apakah kegiatan belajar mengajar dicukupkan, apakah metodenya diubah, apakah kegiatan yang lalu perlu diulang, manakala siswa belum dapat mencapai tujuan-tujuan pembelajaran. Pada tahap 


\section{Dewi Nofrita - Pengembangan Kompetensi Guru ...}

ini disamping pengetahuan teori belajar mengajar, pengetahuan tentang siswa, diperlukan pula kemahiran dan keterampilan teknik belajar, misalnya: prinsip-prinsip mengajar, penggunaan alat bantu pengajaran, penggunaan metode mengajar, dan keterampilan menilai hasil belajar siswa.

Depdiknas (2004:9) mengemukakan kompetensi melaksanakan proses belajarmengajar meliputi (1) membuka pelajaran,(2) menyajikan materi, (3) menggunakan media dan metode, (4) menggunakan alat peraga, (5) menggunakan bahasa yang komunikatif, (6) memotivasi siswa, (7) mengorganisasi kegiatan, (8) berinteraksi dengan siswa secara komunikatif, (9) menyimpulkan pelajaran, (10) memberikan umpan balik, (11) melaksanakan penilaian, dan (12) menggunakan waktu.

Dengan demikian, dapat dikatakan bahwa melaksanakan proses belajar mengajar merupakan sesuatu kegiatan dimana berlangsung hubungan antara manusia, dengan tujuan membantu perkembangan dan menolong keterlibatan siswa dalam pembelajaran. Pada dasarnya melaksanakan proses belajarmengajaradalah menciptakanlingkungan dan suasana yang dapat menimbulkan perubahan struktur kognitif para siswa.

(3) Kompetensi Melaksanakan Penilaian Proses Belajar Mengajar

Menurut Sutisna (1993:212), penilaian proses belajar mengajar dilaksanakan untuk mengetahui keberhasilan perencanaan kegiatan belajar mengajar yang telah disusun dan dilaksanakan. Penilaian diartikan sebagai proses yang menentukan betapa baik organisasi program atau kegiatan yang dilaksanakan untuk mencapai maksudmaksud yang telah ditetapkan.

Depdiknas (2004:9) mengemukakan kompetensi penilaian belajar peserta didik, meliputi (1) mampu memilih soal berdasarkan tingkat kesukaran, (2) mampu memilih soal berdasarkan tingkat pembeda, (3) mampu memperbaiki soal yang tidak valid, (4) mampu memeriksa jawaban, (5) mampu mengklasifikasi hasil-hasil penilaian, (6) mampu mengolah dan menganalisis hasil penilaian, (7) mampu membuat interpretasi kecenderungan hasil penilaian, (8) mampu menentukan korelasi soal berdasarkan hasil penilaian, (9) mampu mengidentifikasi tingkat variasi hasil penilaian, (10) mampu menyimpulkan dari hasil penilaian secara jelas dan logis, (11) mampu menyusun program 
tindak lanjut hasil penilaian, (12) mengklasifikasi kemampuan siswa, (13) mampu mengidentifikasi kebutuhan tindak lanjut hasil penilaian, (14) mampu melaksanakan tindak lanjut, (15) mampu mengevaluasi hasil tindak lanjut, dan (16) mampu menganalisis hasil evaluasi program tindak lanjut hasil penilaian.

\section{(b) Kompetensi Profesional}

Menurut Undang-undang No. 14 tahun 2005 tentang Guru dan Dosen, kompetensi profesional adalah "kemampuan penguasaan materi pelajaran secara luas dan mendalam". Surya (2003:138) mengemukakan kompetensi profesional adalah berbagai kemampuan yang diperlukan agar dapat mewujudkan dirinya sebagai guru profesional. Kompetensi profesional meliputi kepakaran atau keahlian dalam bidangnya yaitu penguasaan bahan yang harus diajarkannya beserta metodenya, rasa tanggung jawab akan tugasnya dan rasa kebersamaan dengan sejawat guru lainnya.

Depdiknas (2004:9) mengemukakan kompetensi profesional meliputi (1) pengembangan profesi, (2) pemahaman wawasan, dan (3) penguasaan bahan kajian akademik.

Pengembangan profesi meliputi (1) mengikuti informasi perkembangan iptek yang mendukung profesi melalui berbagai kegiatan ilmiah, (2) mengalihbahasakan buku pelajaran/karya ilmiah, (3) mengembangkan berbagai model pembelajaran, (4) menulis makalah, (5) menulis/menyusun diktat pelajaran, (6) menulis buku pelajaran, (7) menulis modul, (8) menulis karya ilmiah, (9) melakukan penelitian ilmiah (action research), (10) menemukan teknologi tepat guna, (11) membuat alat peraga/media, (12) menciptakan karya seni, (13) mengikuti pelatihan terakreditasi, (14) mengikuti pendidikan kualifikasi, dan (15) mengikuti kegiatan pengembangan kurikulum.

Pemahaman wawasan meliputi (1) memahami visi dan misi, (2) memahami hubungan pendidikan dengan pengajaran, (3) memahami konsep pendidikan dasar dan menengah, (4) memahami fungsi sekolah, (5) mengidentifikasi permasalahan umum pendidikan dalam hal proses dan hasil belajar, (6) membangun sistem yang menunjukkan keterkaitan pendidikan dan luar sekolah.

Penguasaan bahan kajian akademik meliputi (1) memahami struktur pengetahuan, (2) menguasai substansi materi, (3) menguasai substansi kekuasaan sesuai dengan jenis pelayanan yang dibutuhkan siswa. 


\section{Dewi Nofrita - Pengembangan Kompetensi Guru ...}

\section{(c) Kompetensi Pribadi}

Guru sebagai tenaga pendidik yang tugas utamanya mengajar, memiliki karakteristik kepribadian yang sangat berpengaruh terhadap keberhasilan pengembangan sumber daya manusia. Kepribadian yang mantap dari sosok seorang guru akan memberikan teladan yang baik terhadap anak didik maupun masyarakatnya, sehingga guru akan tampil sebagai sosok yang patut "digugu" (ditaati nasehat/ucapan/ perintahnya) dan "ditiru" (di contoh sikap dan perilakunya).

Kepribadian guru merupakan faktor terpenting bagi keberhasilan belajar anak didik. Dalam kaitan ini, Zakiah Darajat dalam Syah (2000:225-226) menegaskan bahwa kepribadian itulah yang akan menentukan apakah ia menjadi pendidik dan pembina yang baik bagi anak didiknya, ataukah akan menjadi perusak atau penghancur bagi masa depan anak didiknya terutama bagi anak didik yang masih kecil (tingkat dasar) dan mereka yang sedang mengalami kegoncangan jiwa (tingkat menengah). Karakteristik kepribadian yang berkaitan dengan keberhasilan guru dalam menggeluti profesinya adalah meliputi fleksibilitas kognitif dan keterbukaan psikologis. Fleksibilitas kognitif atau keluwesan ranah cipta merupakan kemampuan berpikir yang diikuti dengan tindakan secara simultan dan memadai dalam situasi tertentu. Guru yang fleksibel pada umumnya ditandai dengan adanya keterbukaan berpikir dan beradaptasi. Selain itu, ia memiliki resistensi atau daya tahan terhadap ketertutupan ranah cipta yang prematur dalam pengamatan dan pengenalan.

Dalam Undang-undang Guru dan Dosen dikemukakan kompetensi kepribadian adalah "kemampuan kepribadian yang mantap, berakhlak mulia, arif, dan berwibawa serta menjadi teladan peserta didik". Surya (2003:138) menyebut kompetensi kepribadian ini sebagai kompetensi personal, yaitu kemampuan pribadi seorang guru yang diperlukan agar dapat menjadi guru yang baik. Kompetensi personal ini mencakup kemampuan pribadi yang berkenaan dengan pemahaman diri, penerimaan diri, pengarahan diri, dan perwujudan diri.

Gumelar dan Dahyat (2002:127) merujuk pada pendapat Asian Institut for Teacher Education, mengemukakan kompetensi pribadi meliputi (1) pengetahuan tentang adat istiadat baik sosial maupun agama, (2) pengetahuan tentang budaya dan tradisi, (3) pengetahuan tentang inti demokrasi, (4) pengetahuan tentang estetika, (5) memiliki 
apresiasi dan kesadaran sosial, (6) memiliki sikap yang benar terhadap pengetahuan dan pekerjaan, (7) setia terhadap harkat dan martabat manusia. Sedangkan kompetensi guru secara lebih khusus lagi adalah bersikap empati, terbuka, berwibawa, bertanggung jawab dan mampu menilai diri pribadi. Johnson sebagaimana dikutip Anwar (2004:63) mengemukakan kemampuan personal guru, mencakup (1) penampilan sikap yang positif terhadap keseluruhan tugasnya sebagai guru, dan terhadap keseluruhan situasi pendidikan beserta unsur-unsurnya, (2) pemahaman, penghayatan dan penampilan nilainilai yang seyogyanya dianut oleh seorang guru, (3) kepribadian, nilai, sikap hidup ditampilkan dalam upaya untuk menjadikan dirinya sebagai panutan dan teladan bagi para siswanya. Arikunto (1993:239) mengemukakan kompetensi personal mengharuskan guru memiliki kepribadian yang mantap sehingga menjadi sumber inspirasi bagi subyek didik, dan patut diteladani oleh siswa.

\section{(d) Kompetensi Sosial}

Guru yang efektif adalah guru yang mampu membawa siswanya dengan berhasil mencapai tujuan pengajaran. Mengajar di depan kelas merupakan perwujudan interaksi dalam proses komunikasi. Menurut Undang-undang Guru dan Dosen kompetensi sosial adalah "kemampuan guru untuk berkomunikasi dan berinteraksi secara efektif dan efisien dengan peserta didik, sesama guru, orangtua/wali peserta didik, dan masyarakat sekitar". Surya (2003:138) mengemukakan kompetensi sosial adalah kemampuan yang diperlukan oleh seseorang agar berhasil dalam berhubungan dengan orang lain. Dalam kompetensi sosial ini termasuk keterampilan dalam interaksi sosial dan melaksanakan tanggung jawab sosial.

Gumelar dan Dahyat (2002:127) merujuk pada pendapat Asian Institut for Teacher Education, menjelaskan kompetensi sosial guru adalah salah satu daya atau kemampuan guru untuk mempersiapkan peserta didik menjadi anggota masyarakat yang baik serta kemampuan untuk mendidik, membimbing masyarakat dalam menghadapi kehidupan di masa yang akan datang.

Untuk dapat melaksanakan peran sosial kemasyarakatan, guru harus memiliki kompetensi (1) aspek normatif kependidikan, yaitu untuk menjadi guru yang baik tidak cukup digantungkan kepada bakat, kecerdasan, dan kecakapan saja, tetapi juga harus beritikad baik 
sehingga hal ini bertautan dengan norma yang dijadikan landasan dalam melaksanakan tugasnya, (2) pertimbangan sebelum memilih jabatan guru, dan (3) mempunyai program yang menjurus untuk meningkatkan kemajuan masyarakat dan kemajuan pendidikan. Johnson sebagaimana dikutip Anwar (2004:63) mengemukakan kemampuan sosial mencakup kemampuan untuk menyesuaikan diri kepada tuntutan kerja dan lingkungan sekitar pada waktu membawakan tugasnya sebagai guru. Arikunto (1993:239) mengemukakan kompetensi sosial mengharuskan guru memiliki kemampuan komunikasi sosial baik dengan peserta didik, sesama guru, kepala sekolah, pegawai tata usaha, bahkan dengan anggota masyarakat.

Berdasarkan uraian di atas, kompetensi sosial guru dalam penelitian ini akan diukur melalui indikator (1) interaksi guru dengan siswa, (2) interaksi guru dengan kepala sekolah, (3) interaksi guru dengan rekan kerja, (4) interaksi guru dengan orang tua siswa, dan (5) interaksi guru dengan masyarakat.

\section{Keterkaitan Kemampuan Guru Pendidikan Dasar dengan Keberhasilan Proses Kependidikan}

Proses kependidikan bertujuan untuk mengembangkan potensi peserta didik secara optimal, yang memungkinkan peserta didik dapat mencapai tujuan yang diharapkan, dan bertanggung jawab sebagai anggota masyarakat. Upaya pencapaian tujuan tersebut, banyak hal yang harus dipenuhi serta diperhatikan dari berbagai faktor baik guru secara langsung atau tidak langsung yang dapat mempengaruhi proses belajar peserta didik.

Beberapa faktor yang harus diperhatikan dalam proses kependidikan adalah faktor kemampuan guru dalam melaksanakan proses kependidikan dengan adanya interaksi antara guru dengan peserta didik. Faktor tersebut harus dimiliki guru di dalam melaksanakan proses belajar-mengajar dan terdapat bermacam perbedaan. Perbedaan-perbedaan tersebut antara lain disebabkan oleh kemampuan guru dalam mengajar, pengetahuan yang dimiliki dan latar belakang pendidikan. Hal ini seperti, yang diungkapkan oleh Moh. Surya bahwa pengetahuan guru baik tentang subyek materi, pengetahuan tentang peserta didik maupun pengusaan proses belajar mengajar secara keseluruhan menentukan hasil belajar peserta didik. 
Demikian halnya peserta didik yang mengikuti pelajaran belum tentu mereka dapat menangkap apa yang disampaikan oleh guru. Seringkali guru sebagian besar tidak memberikan respon terhadap tingkah laku peserta didik di dalam kelas. Hal ini seperti dijelaskan oleh S. Nasution (dalam Rusyan, 1993:15) sebagai berikut: "Kalau murid tidak memahami apa yang dikatakan atau disampaikan oleh guru, atau apabila, guru tidak dapat berkomunikasi dengan murid, maka besar kemungkinan murid tidak dapat menguasai mata pelajaran yang diajarkan oleh guru".

Bila hal ini terjadi pada peserta didik, maka sedikit sekali kemungkinan untuk memperoleh prestasi yang diharapkan. Keberhasilan peserta didik belajar dapat dipengaruhi oleh pihak peserta didik sendiri dan dari luar pihak peserta didik. Dari pihak peserta didik meliputi: bakat, motivasi belajar, ketekunan waktu dan kelengkapan sarana di rumah. Sedangkan dari luar pihak peserta didik misalnya tentang kemampuan guru yang baik, disiplin di sekolah dan dorongan serta perhatian dari orang tua.

Kemampuan guru pendidikan dasar dalam proses kependidikan dapat dirasakan dan dipantau oleh peserta didik dalam bentuk-bentuk antara lain:

(a) Peserta didik dapat mengikuti penyajian guru.

(b) Penyajian bahan tidak terlalu cepat.

(c) Contoh-contoh dan soal-soal latihan diberikan, secara cukup.

(d) Guru membantu peserta didik mengingat pelajaran-pelajaran yang pernah diperoleh, dan guru mengerti serta mengenal masalah belajar peserta didik.

(e) Guru berusaha menjawab pertanyaan peserta didik seandainya peserta didik belum mengerti.

(f) Guru membahas soal-soal latihan/tes yang tidak dapat dipecahkan oleh peserta didik.

Diharapkan agar upaya yang dilakukan guru pendidikan dasar seperti langkah-langkah di atas dapat membantu peserta didik mengikuti proses kependidikan dengan baik.

Dalam proses penyajian ini, tentu adahal-hal yang harus diketahui peserta didik sebagai pengetahuan siap yang dapat menunjang proses 
belajarnya. Kadangkala sering ditemukan bahwa pengetahuan siap sebagai prasyarat itu sudah mulai memudar atau terlupakan sama sekali oleh peserta didik. Cara mengatasinya, guru pendidikan dasar perlu sekali-sekali menyelingi dengan pertanyaan- pertanyaan yang mengingatkan peserta didik terhadap bagian-bagian itu, dan kalau perlu memberitahukan apa yang seharusnya sudah diketahui. Hal ini berarti guru pendidikan dasar harus menyadari bahwa apa yang telah diajarkan sebagian memudar dan akan hilang sama sekali. Dalam hal ini dijelaskan oleh Hasibuan bahwa, "Mengajar di depan kelas merupakan perwujudan interaksi dalam proses komunikasi. Guru sebagai pemegang kunci sangat menentukan keberhasilan belajar."

Semakinjelaslahbahwafaktorkemampuansangatpentingdimiliki oleh setiap guru pendidikan dasar dalam proses kependidikan, karena semakin tinggi kemampuan guru dalam melaksanakan proses kependidikan, diduga makin tinggi pula prestasi belajar yang dicapainya.

\section{E. Upaya Meningkatkan Kemampuan Guru}

Menurut Rusyan (1993:250), permasalahan yang dihadapi dalam meningkatkan kemampuan guru dalam proses belajar mengajar dapat digolongkan ke dalam 2 (dua) macam, yaitu permasalahan yang ada di dalam diri guru itu sendiri dan permasalahan yang ada di luar diri. Upaya mengatasi permasalahan-permasalahan tersebut diantaranya dapat dilakukan dengan menumbuhkan kreativitas para guru di lapangan.

\section{(a) Menumbuhkan Kreativitas Guru}

Berbagai ide tentang pembaharuan atau perubahan dalam praktek kependidikan ada yang datang dari atas, ada yang datang dari bawah. Dalampraktekkependidikankita,padaumumnyaperubahan-perubahan yang terjadi datang dan hilang. Hal ini menimbulkan kesan seolaholah para guru sebagai pelaksana di lapangan kurang memiliki kreativitas untuk memperbaiki mutu hasil belajar siswanya. Padahal ada kemungkinan bagi guru untuk memperbaiki mutu hasil belajar siswanya serta mempunyai ide yang kreatif yang dapat menjadi sumbangan berharga bagi upaya peningkatan mutu pendidikan. Para guru dipandang sebagai orang yang paling mengetahui kondisi belajar dan permasalahan belajar yang dihadapi oleh para siswanya, karena hampir setiap hari berhadapan dengan mereka. Guru kreatif 
selalu mencari cara bagaimana agar proses berupaya menyesuaikan pola-pola tingkah lakunya dalam mengajar sesuai dengan tuntutan pencapaian tujuan, dengan memperkembangkan faktor situasi kondisi belajar siswa. Kreativitas yang demikian, memungkinkan guru yang bersangkutan menemukan bentuk-bentuk mengajar yang sesuai, terutama dalam memberi bimbingan rangsangan, dorongan dan arahan agar siswa dapat belajar secara efektif.

Tumbuhnya kreativitas di kalangan para guru memungkinkan terwujudnya ide perubahan dan upaya peningkatan secara terus menerus, dan sesuai dengan situasi dan kondisi lingkungan masyarakat di mana sekolah berada. Di samping itu, tuntutan untuk meningkatkan kemampuan pun muncul dari dalam diri sendiri, tanpa menunggu ide ataupun perintah dari atas.

Kreativitas biasanya diartikan sebagai kemampuan untuk menciptakan suatu produk baru, baik yang benar-benar baru sama sekali, maupun merupakan modifikasi atau perubahan dengan mengembangkanhal-halyang sudahada. Bilakonsepini dikaitkan dengan kreativitas guru, guru yang bersangkutan mungkin menciptakan suatu strategi mengajar yang benar-benar baru dan orisinil (asli ciptaan sendiri), atau dapat saja merupakan modifikasi dari berbagai strategi yang ada sehingga menghasilkan bentuk baru.

Kreativitas secara umum dipengaruhi kemunculan oleh adanya berbagai kemampuan yang dimiliki, sikap dan minat yang positif tinggi kepada bidang pekerjaan yang ditekuni, serta kecakapan melaksanakan tugas-tugas. Tumbuhnya kreativitas di kalangan para guru dipengaruhi oleh beberapa hal, di antaranya

(1) Iklim kerja memungkinkan para guru dapat meningkatkan pengetahuan dan kecakapan dalam melaksanakan tugas.

(2) Kerjasama antara berbagai personil pendidikan dalam memecahkan permasalahan yang dihadapi cukup baik.

(3) Pemberian penghargaan dan dorongan semangat terhadap setiap upaya yang bersifat positif dari para guru untuk meningkatkan prestasi belajar siswa.

(4) Perbedaan status di antara personil sekolah tidak terlalu tajam, sehingga memungkinkan terjalinnya hubungan manusiawi yang lebih harmonis. 
(5) Memberi kepercayaan kepada para guru untuk meningkatkan diri dan mempertunjukkan karya dan gagasan kreatifnya.

(6) Melimpahkan kewenangan yang cukup besar kepada guru dalam melaksanakan tugas dan memecahkan permasalahan yang dihadapi dalam pelaksanaan tugas.

(7) Memberi kesempatan kepada para guru untuk mengambil bagian dalam merumuskan kebijaksanaan-kebijaksanaan yang berkaitan dengan kegiatan pendidikan di sekolah yang bersangkutan, khususnya yang berkaitan dengan peningkatan hasil belajar.

(b) Penataran dan Lokakarya

Pelaksanaan penataran dan lokakarya untuk meningkatkan kemampuan guru dalam melaksanakan proses belajar-mengajar dapat dilakukan oleh sekelompok guru yang mempunyai maksud yang sama dan pelaksanaannya dilakukan dengan cara mengundang seorang atau beberapa orang pakar sebagai nara sumber. Para pakar diminta memberi penjelasan, informasi dan dasar-dasar pengetahuan yang berkaitan dengan apa yang dilokakaryakan. Setelah peserta memperoleh pengetahuan dasar, selanjutnya dilakukan diskusi untuk mengembangkan wawasan, dan disusul dengan latihan untuk meningkatkan kemampuan dan keterampilan mengajar. Latihan yang dilakukan meliputi penyusunan rencana pengajaran, pelaksanaan pengajaran, perencanaan pelaksanaan penilaian hasil belajar.

Di samping ceramah, diskusi, dan latihan dapat pula dilakukan karyawisata ke suatu tempat yang erat kaitannya dengan masalah yang dilokakaryakan. Untuk mengembangkan dan memperluas wawasan, dapat pula ditambah dengan acara belajar di perpustakaan bahan-bahan yang dipelajari sebaiknya disusun secara tertulis dalam bentuk makalah biasa, atau dalam bentuk program, paket belajar atau modul sehingga setiap peserta dapat belajar secara efektif

Pelaksanaan latihan dalam lokakarya dapat memanfaatkan metode supervisi klinis, atau pengajaran mikro, sebagaimana dijelaskan pada uraian berikut. Dengan demikian, para guru bukan hanya memperoleh bekal-bekal pengetahuan, tetapijuga dapatmeningkatkan kemampuan dan keterampilan mengajarnya. Untuk mengetahui penambahan atau peningkatan pengetahuan, kemampuan maupun keterampilan sebagai hasil pelaksanaan lokakarya, pada akhir kegiatan dilakukan evaluasi. Pelaksanaan evaluasi ini bersifat menilai diri 
sendiri, dengan menggunakan panduan yang disusun oleh pakar yang diundang, atau oleh panitia yang menyelenggarakan kegiatan tersebut. Hasil evaluasi dapat dijadikan balikan, baik bagi peserta, maupun bagi penyelenggara.

(c) Supervisi

Supervisi dilakukan dengan tujuan untuk meningkatkan kemampuan dalam proses belajar mengajar melalui upaya menganalisis berbagai bentuk tingkah laku pada saat melaksanakan program belajar mengajar. Pelaksanaan supervisi dapat dilakukan oleh dua orang atau lebih, yang sama-sama ingin meningkatkan kemampuannya dalam melaksanakan proses belajar mengajar. Mereka secara bergantian melakukan pengamatan terhadap berbagai tingkah laku masing-masing pada saat melaksanakan proses belajar mengajar. Sebelum pelaksanaan pengamatan terlebih dahulu dibicarakan tentang bentuk-bentuk tingkah laku apa yang menjadi fokus pengamatan, dan secara bersama disusun panduannya. Berdasarkan panduan itu, dilakukan pengamatan, untuk melihat di mana letak kelemahan-kelemahannya. Setelah masing-masing mengetahui kelemahan diri sendiri, sebagai dasar upaya melakukan perbaikan dan peningkatan kemampuan.

(1) Langkah persiapan

- merundingkan dengan teman sekerja untuk berupaya meningkatkan kemampuan dalam proses belajar-mengajar,

- merundingkan fokus yang akan diamati dari pelaksanaan pengajaran. Pertimbangan menentukan fokus didasarkan atas jenis kemampuan yang ingin ditingkatkan (contoh: bagaimana memberi penjelasan, mengajukan pertanyaan, membimbing diskusi, atau membimbing siswa melakukan penemuan).

- merumuskan alat-alat atau panduan melakukan pengamatan terhadap bentuk-bentuk tingkah laku tertentu sesuai dengan fokus, didasarkan atas tolok ukur tertentu.

- merundingkan siapa terlebih dahulu melakukan pengamatan, dan siapa kemudian, sehingga secara bergiliran masing-masing melakukan pengamatan.

(2) Pelaksanaan Pengamatan

- denganmenggunakan panduanyangsudah disusunsebagai pegangan, 


\section{Dewi Nofrita - Pengembangan Kompetensi Guru ...}

dilakukan pengamatan secermat mungkin terhadap tingkah laku guru dalam melaksanakan proses belajar-mengajar.

- membuat catatan singkat tentang segi-segi yang menyangkut tingkah laku, dan reaksi siswa selama proses belajar-mengajar berlangsung.

- $\quad$ membuat ulasan mengenai hal-hal yang dipandang perlu diulas. Ulasan dicatat dalam lembaran lain di luar panduan pengamatan.

- Kepedulian pengamatan terbatas pada hal-hal yang menjadi fokus semata-mata.

(3) Pembahasan Hasil Pengamatan

Setelah selesai pengajaran dilakukan pembahasan bersama antara pengajar dan pengamat, yang meliputi :

- pembahasan dimulai dengan mengemukakan segi-segi positif dari proses belajar-mengajar yang diamati.

- menunjukkan beberapa kelemahan dari proses belajar-mengajar kemudian dibahas mengapa hal itu terjadi, serta bagaimana kemungkinan menghindarinya, sebagai dasar untuk latihan pada proses belajar-mengajar berikutnya.

- Jika ternyata guru yang bersangkutan menemui kesulitan dalam menampilkan segi-segi tingkah laku tertentu dalam pelaksanaan proses belajar-mengajar, dapat dilakukan latihan terlebih dahulu sebelum memulai pengajaran. Untuk memudahkan pelaksanaannya, terlebih dahulu dilakukan kajian tentang kemampuan mana yang terlebih dahulu diupayakan untuk ditingkatkan sehingga secara bertahap tuntutan kemampuan minimal dalam proses belajar-mengajar dapat tercapai.

(d) Pengajaran Mikro

Pengajaran mikro secara praktek dimaksudkan untuk melatih kemampuan melaksanakan proses belajar-mengajar. Di dalam melaksanakan proses belajar mengajarnya dapat dilaksanakan oleh sekelompok guru (biasanya antara 5 sampai 10 orang) di suatu sekolah. Karena praktek latihan ini bersifat khusus, maka pelaksanaannya dilakukan di luar kegiatan mengajar sebenarnya. Pelaksanaan kegiatan dilakukan dengan cara, seorang guru bertindak sebagai pengajar, sedangkan guru-guru yang lain menjadi siswa yang melakukan 
proses belajar. Kegiatan semacam ini merupakan suatu cara untuk bekerjasama untuk meningkatkan kemampuan dalam melaksanakan pengajaran.

(1) Ciri-ciri pengajaran mikro adalah sebagai berikut:

- Pengajaran mikro merupakan praktek pengajaran yang sebenarnya, bukan simulasi mengajar yang bersifat pura-pura, dengan memanfaatkan teman sekerja sebagai siswa. Sebagaimana pengajaran yang ingin dicapai, ada rencana pengajaran, rencana kegiatan untuk mencapai tujuan, metode dan alat apa yang akan digunakan, dan penilaian hasil belajar.

- Sebagai pengajar yang sebenarnya, dalam pengajaran mikro ada bahan pelajaran atau bentuk-bentuk pengalaman belajar, baik berupa pengetahuan, maupun keterampilan yang akan dicapai setelah proses belajar-mengajar serta, kegiatan apa yang seharusnya dilakukan siswa (teman sekerja yang menjadi siswa) untuk memperoleh pengalaman belajar tersebut.

- Perbedaan pengajaran mikro dari pengajaran biasa yaitu, dalam pengajaran mikro waktu yang digunakan cukup pendek (sekitar 20 menit), siswanya sedikit (5 sampai 10 orang), dan bahannya pun terbatas.

- Pelaksanaan pengajaran mikro terpusat pada latihan bentukbentuk keterampilan tertentu yang ingin ditingkatkan kemampuannya. Oleh karena itu, selagi dilakukan praktek pengajaran, sebaiknya ada orang lain yang melakukan pengamatan terhadap tingkah laku mengejar, bisa menggunakan alat rekaman video, agar setelah selesai pelaksanaan pengajaran dapat dilakukan pembahasan.

(2) Langkah-langkah dalam melaksanakan pengajaran mikro adalah sebagai berikut:

- Menghubungi teman sekerja atau guru-guru yang mau diajak kerjasama untuk meningkatkan kemampuan.

- Memberitahukan siapa yang akan melaksanakan praktek mengajar, siapa yang menjadi siswa, dan siapa yang menjadi pengamat.

- Merumuskan bentuk kemampuan yang akan dilatihkan. 


\section{Dewi Nofrita - Pengembangan Kompetensi Guru ...}

- Menyusun panduan pengamatan berdasarkan bentuk kemampuan yang dilatihkan.

- Bagi yang akan melakukan praktek (latihan mengajar) menyusun satuan pengajaran untuk mengajar mikro, sebagaimana bentuk rencana pengajaran biasa.

- Melaksanakan pengajaran mikro sebagaimana pengajaran biasa.

- Berdasarkan hasil pengamatan dari para pengamat, setelah selesai pengajaran dilakukan upaya pembaharuan, dengan mengemukakan segi-segi tingkah laku positif dan negatif ketika mengajar, dan dilakukan diskusi oleh semua yang terlibat dalam pengajaran mikro, yaitu orang yang bertindak sebagai guru, siswa dan pengamat. Sebagai catatan akhir, upaya meningkatkan kemampuan melaksanakan proses belajar mengajar, sepatutnya didorong oleh rasa kebutuh dari setiap guru, atau atas kesadaran sendiri. Dengan dorongan yang muncul dari dalam diri sendiri diharapkan kemampuan selalu meningkat dari waktu ke waktu. Hal ini akan membawa dampak kepada keberhasilan upaya peningkatan mutu pendidikan.

\section{F. Penutup}

Guru pendidikan dasar merupakan suatu profesi yang artinya suatu jabatan atau pekerjaan yang memerlukan keahlian khusus sebagai guru. Jenis pekerjaan ini mestinya tidak dapat dilakukan oleh sembarang di luar bidang kependidikan walaupun kenyataannya masih terdapat dilakukan orang di luar kependidikan.

Peranan Guru Pendidikan Dasar: (1) guru pendidikan dasar sebagai demonstrator. (2) guru pendidikan dasar sebagai pengelola kelas, (3) guru pendidikan dasar sebagai mediator dan fasilitator, (4) guru pendidikan dasar sebagai evaluator. Syarat profesional menjadi guru profesiona: (1) persyaratan fisik, (2) Persyaratan psychis, (3) persyaratan mental (4), persyaratan moral, (5) persyaratan intelektual. Karakteristik kemampuan guru pendidikan dasar: (1) mampu mengembangkan tanggung jawab dengan sebaik-baiknya, (2) mampu melaksanakan peranannya secara berhasil, (3) mampu bekerja dalam usaha mewujudkan tujuan pendidikan di sekolah, dan .mampu melaksanakan peranannya dalam proses belajar-mengajar di kelas. Merujuk pada Undang-undang Guru dan Dosen dimensi kompetensi yang 
dibutuhkan guru adalah dimensi (1) pedagogik, (2) profesional, (3) pribadi, dan (4) sosial.

Kemampuan guru pendidikan dasar dalam proses kependidikan dapat dirasakan dan dipantau oleh peserta didik dalam bentuk-bentuk antara lain: (1) Peserta didik dapat mengikuti penyajian guru. (2) Penyajian bahan tidak terlalu cepat. (3) Contoh-contoh dan soal-soal latihan diberikan, secara cukup. (4) Guru membantu peserta didik mengingat pelajaran-pelajaran yang pernah diperoleh, dan guru mengerti serta mengenal masalah belajar peserta didik.(5) Guru berusaha menjawab pertanyaan peserta didik seandainya peserta didik belum mengerti. (6) Guru membahas soal-soal latihan/tes yang tidak dapat dipecahkan oleh peserta didik.

\section{G. Daftar Pustaka}

A. Tabrani Rusyan. (1993). Peningkatan Kemampuan Guru Pendidikan Dasar. Bandung: Bina Budhaya.

Anwar, Moch. Idochi. (2004). Administrasi Pendidikan dan Manajemen Biaya Pendidikan. Bandung: Alfabeta

Arikunto, Suharsimi (1993). Manajemen Pengajaran Secara Manusia. Jakarta: Rineka Cipta

Harahap, Baharuddin. (1983). Supervisi Pendidikan yang Dilaksanakan oleh Guru, Kepala Sekolah, Penilik dan Pengawas Sekolah. Jakarta: Damai Jaya.

Joni, T. Raka. (1984). Pedoman Umum Alat Penilaian Kemampuan Guru. Jakarta: Dirjen Pendidikan Tinggi Depdikbud

Surya, Mochamad (1979). Pengaruh Faktor Intelejensi terhadap Motivasi Berprestasi. Bandung: IKIP Bandung

Surya, Muhammad. (2003). Psikologi Pembelajaran dan Pengajaran. Bandung: Yayasan Bhakti Winaya.

Sutisna, Oteng. (1993). Administrasi Pendidikan Dasar Teoritis dan Praktis Profesional. Bandung: Angkasa

Syah, Muhibbin. (2000). Psikologi Pendidikan dengan Pendekatan Baru. Bandung: PT Remaja Rosdakarya.

Undang-undang No. 14 Tahun 2005 tentang Guru dan Dosen 
Dewi Nofrita - Pengembangan Kompetensi Guru ...

Undang-undang Nomor 20 Tahun 2003 Tentang Sistem Pendidikan Nasional.

Yutmini, Sri. (1992). Strategi Belajar Mengajar. Surakarta: FKIP UNS.

222 Madrasah, Vol. 4 No. 2 Januari - Juni 2012 